\title{
The Political Consequences of Electoral Laws in Latin America and the Caribbean
}

\author{
MARK P. JONES* \\ Department of Political Science, University of Michigan, Ann Arbor, \\ MI 48109-1045, USA
}

\begin{abstract}
This article revisits Arend Liphart's (1990) re-analysis of Douglas Rae's The Political Consequences of Electoral Law's (1971) using data from Latin America and the Caribbean. The findings of this study concur with much of Lijphart's analysis. However, contrary to Lijphart, a positive relationship was found between disproportionality and multipartism for PR systems. Particularly well supported were Lijphart's finding of (1) an inverse relationship between district magnitude and disproportionality and (2) a strong relationship between electoral formula and disproportionality. The article demonstrates the applicability of a portion of Anglo-European theory to party systems in a region with democratic histories and economic profiles which are radically different from those of the systems upon which Rac and Lijphart bascd thcir findings.
\end{abstract}

During the past decade the world witnessed a progressive growth in the number of nations conducting generally free competitive elections, and, for the most part, conforming to the norms of democratic society. While both popular and academic presses have devoted many pages to the description of the growth of parties and the administration of elections in these incipient democracies, relatively little attention has been given to the examination of electoral laws. There has been little discussion of how various laws might affect the current and future types of party systems and representation in government in 'democratizing' countries. Since many of these nations have based their electoral system on Anglo-European models, it is both theoretically and practically relevant to assess the applicability of 'First World' theories about electoral structures to nations currently in the process of democratization/redcmocratization. If Anglo-European based theories seem to work, then not only will their importance as part of general theory be increased, but the results of the exercise may be of practical use to policy makers attempting to construct electoral systems in democratizing countries.

The theoretical literature on the impact of electoral laws on party systems has focused primarily on the Anglo-European nations (e.g. Duverger, 1954; Rae, 1971;

"I am indebted to Ruth S. Jones, Warren E. Miller, E. Terrence Jones, Arend Lijphart and Edouard Lehoucq for their helpful comments and suggestions. 
Sartori, 1976).' This article is focused on a specific component of this literature, Douglas Rac's seminal study The Political Consequences of Electoral Laws (Rae, 1971), and Arend Lijphart's re-analysis of it (Lijphart, 1990). In his seminal work Rae found electoral laws to have a noticeable impact on the party systems of the European nations he examined. The impact of Rae's work on the way in which electoral systems are now studied is clear. However in 'The Political Consequences of Electoral Laws, 1945-1985' (1990: 482), Lijphart noted that the Rat study possessed some inherent methodological flaws that called into question the validity of Rate's findings. Lijphart utilized 'more accurate (and substantive) data, stronger hypotheses and better methods' (1990: 481) to test and update Rate's original findings. ${ }^{2}$ While retaining the variables and nations examined by Rae, Lijphart thus corrects for the original methodological weaknesses in Rae's analysis. In contrast to Rae, Lijphart finds electoral formula (that is, the method by which votes are translated into legislative seats) and average district magnitude (that is, the average number of representatives per electoral district) to have a very strong effect on proportionality, yet only a mild impact on multipartism. Lijphart's findings tend to downplay the notion that the electoral rules (within PR systems) have a significant impact on the degree of multipartism in a nation (1990: 482). Whether these findings hold true in a Latin American and Caribbean setting is the subject of our present discussion.

The discussion has six components. First, an overview of Lijphart's salient variables and their operationalization will be detailed. Second, the population of non-Anglo-European countries used in our current sudy and the various constraints encountered in the data collection process will be identified. Third, the findings regarding four salient relationships studied by Lijphart will be individually examined. Lijphart's fifth relationship between ballot structure and multipartism cannot be studied due to a complete lack of variance in the ballot structure variable in the countries under investigation. Fourth, the overall link between disproportionality and multipartism will be addressed. Fifth, while Lijphart's sample was composed of primarily parliamentary systems, a majority of the systems examined here are presidential. Since the timing of the election of the executive has been shown to affect the disproportionality and multipartism of an electoral system (Shugart, 1988), this relationship will be examined utilizing data from the 12 presidential-PR systems in this study. The paper ends with a discussion of both the theoretical and practical implications of the findings.

\section{Structure of Analysis}

Lijphart's re-analysis of Rac's classic study utilizes the two dependent and three independent variables employed by Rac to study the impact of electoral laws on elections for lower houses or unicameral legislatures. Lijphart (1990: 483) modified both of Rate's dependent variables through the use of improved statistical methods. The disproportionality of the electoral result (that is, the disparity in the translation of votes into seats) was measured using Loosemore and Hanby's (1971) index 0.3 Multipartism (that is, the number of effective parties) was calculated utilizing an index of fractionalization based on the percentage of the vote garnered by the various parties in the lower house/unicameral clections.' The analysis that follows employs Lijphart's operationalization and replicates his analysis using data from 22 Latin American and Caribbean nations and territories." 
The first independent variable is the electoral formula. Whereas Rae utilized three classifications when examining electoral formula, Lijphart employed four separate groups: (1) plurality and majority; and then among the proportional representation systems, in hypothesized order from least to most proportional; (2) the d'Hondt formula; (3) the modified Sainte-Laguë, LR-Droop, LR-Imperiali, STV-Droop formulas; and (4) the pure Sainte-Laguë and LR-Hare formulas (Lijphart, 1990: 484-5). This study utilizes the same classifications as Lijphart with the exception of his third category due to the absence of any of these formulas in the systems included in the study.

The second independent variable is the average district magnitude. Lijphart (1990: 486) also modified Rae's original classification system slightly, using five separate categories for the average number of representatives per district: 1-1.1, 1.1-5, 5-10,10-25,100-150. All of the Latin American systems in the present study use categorical ballots and hence there is no variance in ballots; consequently the ballot structure variable was not included in this analysis.

Work by Matthew Shugart has introduced another consideration extending the Rae/Lijphart model. In an analysis of Latin American party systems, Shugart (1988) found that in nations where the presidential elections were held concurrently with those for the national legislature, holding other factors constant, the level of disproportionality and multipartism were lower than was the case in countries where the elections were held at separate times. Shugart, however, did not deal with the cases where the timing of the elections was ambiguous. In the discussion that follows, the independent variable for election timing has been operationalized as a three point ordinal scale based on the degree of temporal concurrence between the presidential and legislative elections.

\section{The Population}

The Latin American and Caribbean region is an ideal area in which to test Lijphart's revision of Rae's original theory and their conclusions that electoral laws matter. First, the culture, political history, and level of economic development of the region's nations are profoundly different from those of the nations upon which Rae and Lijphart based their findings. If we find results regarding the impact of electoral laws that are similar to those of Lijphart, the generalizability of his findings would be greatly strengthened. Second, unlike most of the recent democratizing regions (e.g., Africa, Asia and Eastern Europe), Latin America and the Caribbean not only have a much richer history of democracy than any other non-Anglo-European region, but much of the region began its democratization process earlier. This provides a more extensive set of elections available for analysis and a longer time period for testing. Last, though this study is limited to the Western Hemisphere out of a desire to keep some regional factors constant, the region itself is none the less very diverse. One can contrast the wealth of Venezuela versus the poverty of Honduras; the democratic histories of Costa Rica and Guatemala; the ethnic composition of Uruguay versus Bolivia; the military involvement in politics in Argentina and in Jamaica; and the colonial history of the former Spanish colonies versus that of the former British colonies. In sum, the region represents a rich and challenging environment in which to examine questions related to the impact of electoral structures in a non-Anglo-European setting. 
Three criteria were used to identify the study population and assemble the data for the 22 electoral systems that comprise the final data set. The first criterion was that the elections in question (and therefore the nation) be democratic in nature. For our purposes a democracy is defined as a system in which there occurs 'meaningful and extensive contestation ... a highly inclusive level of political participation ... and a level of civil and political liberties . . sufficient to ensure the integrity of political competition and participation.' (Diamond, Linz and Lipset, 1990: 6-7). Nevertheless, the ultimately arbitrary nature of the selection of particular countries is acknowledged; however. a degrec of arbitrariness in defining 'democratic countries' is hard to avoid.

In regard to the 'democratic' nature of these nations, some might criticize the restriction of the electoral arena to a limited spectrum of parties in some nations, the lack of open participation in others, or the lack of a high degree of civil and political liberties in a select number of nations. Others may criticize the narrow focus on elections as the defining characteristic of a democracy. Finally, many who study the region might question the relative salience of elections to politics in Latin America. While all of these criticisms are in part valid, it is the position of this author that based on the reports of international and local observers, the elections included in this study were democratic. Finally, while onc can debate the relative salience of elections for Latin American politics, their unique role in the expression of mass sentiment and the legitimation of government cannot be overstated.

A second criterion was temporal. Only elections that occurred after a nation became independent were included. This criterion was violated in two cases (Curacao and Puerto Rico) due to the fact that neither country is as yet independent. Inlike the region's French colonies however, the party systems of Curacao

Tiste: 1.

\begin{tabular}{|c|c|}
\hline Country/territory & Elcetions included \\
\hline Argentina & $1983,85,87,89$. \\
\hline Bahamas & $1977,82,87$ \\
\hline Barbados & $1971,76,81,86,91$. \\
\hline Belize & 1984,89 \\
\hline Bolivia & 1985,89 \\
\hline Chile & $1949,53,57,61,65,69,73$. \\
\hline Colombia & $1971,78,82,86$ \\
\hline Costa Rica & $1953,58,62,66,70,78,82,86,90$. \\
\hline (uracio) & 1987 \\
\hline Dominica & 1987 \\
\hline Dominican Republic & $1978,82,86,90$. \\
\hline Ecuador & 1984.86. \\
\hline El Salvador & $1985,88,91$. \\
\hline Guatcmala & 1485 \\
\hline Honduras & 1985,89 \\
\hline Jamaica & $1967,72,76,80,89$ \\
\hline Puerto Rico & $1961,68,72,76,80$. \\
\hline St. Lucia & $1979,82,87,89$ \\
\hline Suriname & 1977 \\
\hline Trinidad and Tobago & $1960,76,81,80$. \\
\hline linuguay & $1942,40,50,51,58,62,60,-1,81,89$ \\
\hline Vencozucla & $1958.63,68.73 .78,83.88$ \\
\hline
\end{tabular}


and Puerto Rico are relatively unaffected by those of the metropolitan power. Moreover these two systems possess a set of unique qualities; they provide a nonHispanic proportional representation system and a Hispanic plurality system respectively, that recommended their inclusion in the study.

A third requisite focused on data availability. The electoral system of a nation had to be amenable to analysis utilizing the methods employed by Lijphart, ${ }^{6}$ and the data for any given election had to be complete in order to be included in the study. In all, data were collected for 86 elections in 22 nations/territories, from which averages were calculated for each of the 22 electoral systems,

Following Lijphart's focus on electoral systems rather than elections, and using Lijphart's variable definitions, the data set assembled permits analysis of the applicability of the four general theories in the Lijphart/Rae work on the impact of electoral formula and district magnitude on electoral disproportionality and multipartism in a set of non-Anglo-European electoral systems.

\section{Electoral Formula and Electoral Disproportionality}

Lijphart found plurality-majority systems to be more disproportional than proportional representation (PR) systems. He also detected a progressive decrease in disproportionality as one moves from the (hypothesized) least proportional PR system (d'Hondt) to the most proportional (LR-Hare and pure Sainte-Laguë) (see Table 2). Finally, Lijphart found that the impact of formula persists when district magnitude is held constant.

TABLE 2. Average degrees of disproportionality of electoral systems classified by electoral formula and adjusted district magnitude for 31 Anglo-European electoral systems (\%)

\begin{tabular}{lccccc}
\hline $\begin{array}{l}\text { Adjusted } \\
\text { district } \\
\text { magnitude }\end{array}$ & $\begin{array}{c}\text { LR-Hare } \\
\text { and pure } \\
\text { Sainte-Lague }\end{array}$ & $\begin{array}{c}\text { LR-Droop } \\
\text { IR-Imporiali } \\
\text { STV-Droop etc }\end{array}$ & d'Hondt & $\begin{array}{c}\text { Plurality } \\
\text { and } \\
\text { majority }\end{array}$ & All \\
\hline $1-1.1$ & - & - & - & $12.93(6)$ & $12.93(6)$ \\
$1.1-5$ & - & $4.60(1)$ & $8.51(3)$ & - & $7.53(4)$ \\
$5-10$ & - & $5.18(3)$ & $5.83(6)$ & - & $5.61(9)$ \\
$10-25$ & $2.81(2)$ & - & $4.28(3)$ & - & $3.69(5)$ \\
$100-150$ & $2.46(3)$ & $5.53(2)$ & $4.39(2)$ & - & $3.32(7)$ \\
AlI $^{*}$ & $2.60(5)$ & $4.53(6)$ & $5.87(14)$ & $12.93(6)$ & $6.45(31)$ \\
\hline
\end{tabular}

Notr: The numbers of cascs on which the percentages are based are in parentheses. *Except France of 1951-56.

Source: (Lijphart, 1990:485)

The Latin American data suggest a similar relationship between formula and disproportionality with plurality systems being the most disproportional, followed by the d'Hondt PR system (the least proportional of the PR family according to Lijphart), concluding with the Hare system. Similarly when we hold district magnitude constant to test for the independent effect of formula, the Latin American data, like Lijphart's, show a similar independent effect in two of the three PR magnitude categories (see rows two and three in Table 3). In sum, the findings of this study are congruent with those of Lijphart regarding the impact of electoral formula on disproportionality. Our findings thus strengthen the generalizability of this portion of Lijphart's theory. 
Thable 3. Average degrees of disproportionality of electoral systems classified by electoral formula and adjusted district magnitude for 22 Latin

American and Caribbean electoral systems (\%)

\begin{tabular}{lcccc}
\hline $\begin{array}{l}\text { Adjusted } \\
\text { district } \\
\text { magnitude }\end{array}$ & $\begin{array}{c}\text { LR-Hare } \\
\text { and pure } \\
\text { Sainte-Laguë }\end{array}$ & d'Hondt & $\begin{array}{c}\text { Plurality } \\
\text { and } \\
\text { majority }\end{array}$ & All \\
\hline $1-1.1$ & - & - & $20.00(8)$ & $20.00(8)$ \\
$1.1-5$ & $10.82(2)$ & $17.51(3)$ & - & $1.85(5)$ \\
$5-10$ & $3.83(3)$ & $10.29(2)$ & - & $6.42(5)$ \\
$10-100$ & $10.50(1)$ & $4.33(3)$ & - & $5.87(1)$ \\
All & $7.27(6)$ & $10.77(8)$ & $20.00(8)$ & $13.17(22)$ \\
\hline
\end{tabular}

Note: The numbers of cases on which the percentages are based are in parentheses.

\section{District Magnitude and Electoral Disproportionality}

In his examination of the impact of district magnitude (that is, the average number of representatives per district) on electoral disproportionality Lijphart (1990: 187) makes some minor alterations in the categories of average district magnitude used by Rae. In contrast to Rae, Lijphart deals with the situation of complex-districting by adjusting the magnitude (that is, boosting the magnitude found for a system's lower tier districting system up one category) for those nations with complex twotier districting. Lijphart finds a noticeable inverse relationship between magnitude and disproportionality (see Table 2). Disproportionality decreases as one moves from lower to higher magnitudes, with the greatest change occurring between the single-member districts and the first multi-member category. Furthermore. Lijphart finds that when one controls for formula, differences between magnitude categories are reduced rather soundly, except within the d'Hondt family where noticeable differences remain."

The findings for the Latin American and Caribbean experience parallel, for the most part, those of Lijphart." Table 3 displays the same inverse relationship between magnitude and disproportionality. Here one notes a progressive decrease in disproportionality beginning with the lowest magnitude category (row one), with the most noticeable drop occurring between the second and third categories (Lijpharts largest decrease occurred between the first and second categories). This finding provides support for Taagepera and shugart's premise that in PR systems a magnitude of at least five or six is required in order to consistently lead to a proportional translation of votes into seats (Taagepera and Shugart, 1989:113-14).

Lijphart held formula constant and found that in two of the PR families, the differences between categories were significantly reduced, but in one (dHondt) they remained noticeable. In Latin America examination of the dHondt category provides support for Lijphart's finding. Even holding formula constant, differences in magnitude are apparent within this category. Data from the Hare ategory are less conclusive, but also tend to support Lijphart's finding of no impact within the non-d'Hondt formulas. In sum. once again strong support is provided for another portion of Lijphart's hypothesis regarding the impact of district magnitude on disproportionality. 
An initial attempt was made to examine the Latin American and Caribbean data utilizing ordinary least squares (OLS) regression analysis. However, due to the problem of multicollinearity implicitly hypothesized by Lijphart (1990: 483) and found in the OLS analysis between the two independent variables (the correlation between formula and magnitude is .80 ), OLS could not be used to determine the independent impact of these two variables on either of the two dependent variables. However, this multicollinearity neither intrudes on the interpretation of the cross tabulations nor minimizes the demonstration of systematic variability within categories. Finally, the two variables in tandem do have a strong impact on disproportionality (explained variance $=.67$ ) ${ }^{10}$

\section{Electoral Formula and Multipartism}

Lijphart detected a noticeable difference in multipartism between plurality and PR systems. However, he failed to find any differences within the PR family (see Table 4). In fact, by controlling for magnitude (see horizontal magnitude categories in Table 4), Lijphart actually undermines any theory stressing a relationship between formula and multipartism within the PR family.

'TABLE 4. Average effective numbers of elective parties in electoral systems classified by electoral formula and adjusted district magnitude for 31 Anglo-European electoral systems

\begin{tabular}{lccccc}
\hline $\begin{array}{l}\text { Adjusted } \\
\text { district } \\
\text { magnitude }\end{array}$ & $\begin{array}{c}\text { LR-Hare } \\
\text { and pure } \\
\text { Sainte-Lague }\end{array}$ & $\begin{array}{c}\text { LR-Droop } \\
\text { LR-Imperiali } \\
\text { STV-Droop etc }\end{array}$ & $\begin{array}{c}\text { Plurality } \\
\text { and } \\
\text { majority }\end{array}$ & All \\
\hline $1-1.1$ & - & - & - & $2.95(6)$ & $2.95(6)$ \\
$1.1-5$ & - & $3.04(1)$ & $3.96(3)$ & - & $3.73(4)$ \\
$5-10$ & - & $3.19(3)$ & $4.10(6)$ & - & $3.80(9)$ \\
$10-25$ & $4.04(2)$ & - & $4.27(3)$ & - & $4.18(5)$ \\
$25-150$ & $4.30(3)$ & $3.75(2)$ & $4.76(2)$ & - & $4.28(7)$ \\
All & $4.20(5)$ & $3.35(6)$ & $4.20(14)$ & $2.95(6)$ & $3.79(31)$ \\
\hline
\end{tabular}

Note: The numbers of cases on which the percentages are based are in parentheses.

*Except France of 1951-56.

Source: (Lijplart, 1990: 490).

The findings on the relationship between formula and multipartism in the Latin American and Caribbean data once again tend to parallel Lijphart's. "As shown in Table 5, no strong relationship within the PR family was discovered. When formula was held constant, in two out of three cases, the d'Hondt systems were more fractionalized than the LR-Hare systems. Finally, a difference between plurality and PR systems was similar to that found by Lijphart (1990: 490).

The difference between plurality-majority systems and the PR systems found by Lijphart (after he restricted his analysis to plurality cases of the plurality-majority systems, which is the unanimous method used by the non-PR systems in this study) was $1.53(4.07-2.54)$. This is somewhat similar to that found in this study 1.17 (3.42-2.25), though the different set of magnitudes and formulas in the two studies prevent us from making any direct comparisons of the data.

In sum, the non-Anglo-European data suggest that in regard to the differences between plurality and PR systems, electoral formula is related to multipartism. 
Furthermore, they provide reasonably strong support for Lijphart's conclusion that formula has no impact on multipartism within the PR family, though the question of why the d'Hondt systems tend to be more fractionalized remains to be explained.

\section{District Magnitude and Multipartism}

In his replication of the impact of district magnitude on multipartism, Lijphart (1990: 490) finds a positive relationship between magnitude and multipartism. As was the case regarding disproportionality, the largest difference Lijphart found was between single-member districts and the smallest multi-member district category, with the differences within the multi-member districts being quite small. Holding formula constant, Lijphart continued to find a similar positive relationship between magnitude and multipartism as can be observed in the vertical PR columns in Table 4.

The Latin American and Caribbean data also tend to exhibit (with one exception) the small positive relationship between magnitude and multipartism (see Table 5). The weakness of these results does, however, call into question the meaningfulness of these findings. This trend of a small monotonic relationship between these two variables is noted in the first, second and fourth magnitude categories, but not the third (5-10). When holding electoral formula constant the relationship between magnitude and multipartism can be described as weak at best, with only two of three magnitude categories in each formula conforming to the hypothesized positive relationship between district magnitude and multipartism.

\section{Electoral Disproportionality and Multipartism}

Lijphart concluded that the independent variables (formula and magnitude) have a strong impact on disproportionality, but a very marginal impact on multipartism. Lijphart explains this situation by noting that disproportionality (which intervenes between the independent variables and multipartism) has a very weak impact on the number of parties in an electoral system. He goes on to qualify this assertion in three ways (1990: 193). First, correcting for the impact of ordinal ballot structure on the correlation between disproportionality and multipartism moves the correlation from -.10 to -29 . Second, Lijphart notes the principal source of this stronger correlation is the plurality-majority systems (high disproportionality and

l'able: 5. Average effective numbers of elective parties in 21 Latin American and Caribbean electoral systems classified by electoral formula and adjusted district magnitude

\begin{tabular}{lcccc}
\hline $\begin{array}{l}\text { Adjusted } \\
\text { district } \\
\text { magnitude }\end{array}$ & $\begin{array}{c}\text { LR-Hare } \\
\text { and pure } \\
\text { Sainte-Laguë }\end{array}$ & d'Hondt & $\begin{array}{c}\text { Plurality } \\
\text { and } \\
\text { majority }\end{array}$ & All \\
\hline $1-1.1$ & - & - & $2.25(8)$ & $2.25(8)$ \\
$1.1-5$ & $2.65(2)$ & $3.85(2)$ & - & $3.25(4)$ \\
$5-10$ & $2.32(3)$ & $4.57(2)$ & - & $3.22(5)$ \\
$10-100$ & $4.80(1)$ & $3.50(3)$ & - & $3.83(4)$ \\
Al. & $2.84(6)$ & $3.90(7)$ & $2.25(8)$ & $2.97(21)$ \\
\hline
\end{tabular}

Note: The numbers of cases on which the above figures are based are in parentheses. 
low multipartism), and that among the PR systems this correlation is a negligible .02. Third, unlike Rae, Lijphart measures multipartism using the number of elective parties rather than the number of legislative parties. He finds that use of this latter measure results in a stronger correlation (-.45, up from -.29) which in part explains some of the differences in his findings from those of Rae. In sum however, Lijphart still finds formula and magnitude (operating through the intervening variable of disproportionality) to have a meagre impact on multipartism.

Analysis of the Latin American and Caribbean data tend to support Lijphart's overall conclusion that while electoral formula and district magnitude do have a salient impact on disproportionality, they tend to have a very minor impact on multipartism. In an examination of these relationships using OLS regression analysis the two independent variables together explained 67 per cent of the variance in disproportionality, yet only 33 per cent of the variance in multipartism. While not completely reliable due to an inability to hold formula constant, a bivariate examination of the impact of district magnitude on disproportionality and multipartism for the PR systems reveals support for Lijphart's hypothesis regarding the impact of magnitude on disproportionality but not for his premise regarding its impact on multipartism. The estimated magnitude coefficient for disproportionality was (-.633) with a $t$-ratio of $(-3.868)$ (12 df) while the same coefficient for multipartism was (.003) with a $t$-ratio of (.027) (11 df). Finally, like Lijphart, our analysis found a very weak correlation (.11), weaker in fact than that found by Lijphart $(-.29)$, between disproportionality and multipartism.

Thus far this study has supported the gencral findings of Lijphart, or Icast not strongly contradicted them. However, this is not the case when one divides the population, as Lijphart did, between plurality systems and PR systems and examines the separate correlations between disproportionality and multipartism. Here, the Latin American and Caribbean data reveal a strong positive correlation between disproportionality and multipartism for both the plurality (.57) and PR systems (.68).

These findings are at odds with those of Lijphart and thus deserve further examination. First, one finds a high positive correlation between the two dependent variables (disproportionality and multipartism) for the plurality systems, which while interesting since the sign is in the opposite direction of that found by Rae, is suspect due to the very low variance of the multipartism variable within the plurality subset (variance $=.033$, with a mean of 2.25 ).

More interesting is the very counterintuitive finding of a strong positive correlation between disproportionality and multipartism for the PR systems (.68). This result is contrary to both Giovanni Sartori's hypothesis of an inverse relationship between these two variables (Sartori, 1986: 54) as well as Lijphart's finding of virtually no correlation between these two variables (.02). This finding thus suggests a limit to the generalizability of traditional Anglo-European assumptions about the relationship between proportionality and multiparty systems.

This positive relationship between disproportionality and multipartism is perhaps due to the presence of a popularly elected president alongside a legislature elected using PR in 12 of the 14 PR cases. It would appear that in these systems the AngloEuropean based assumptions that increased multipartism either leads to decreased disproportionality (Sartori) or has no effect on disproportionality (Lijphart) do not apply. Table 6 tends to support this view, with 10 of the 12 presidential systems falling in the diagonal hypothesized by the positive correlation (that is, moving from the upper left to the lower right corners, but with the two non-presidential systems 
TABLE 6. The relationship between disproportionality and multipartism in Latin American PR systems

\begin{tabular}{|c|c|c|c|c|}
\hline \multirow{4}{*}{ Disproportionality } & & $2-2.5$ & $\begin{array}{c}\text { Multipartism } \\
2.51-3.5\end{array}$ & $3.51-$ \\
\hline & $(0)-5$ & $\begin{array}{l}\text { Colombia } \\
\text { Honduras }\end{array}$ & I ruguay & Curacaro \\
\hline & $5.1-10$ & & $\begin{array}{l}\text { Costa Rica } \\
\text { Dom Republic } \\
\text { El Salvador }\end{array}$ & Venceruela \\
\hline & $10.1-$ & Suriname & & $\begin{array}{l}\text { Bolivia } \\
\text { Chile } \\
\text { Ecuador } \\
\text { Ciuatemala }\end{array}$ \\
\hline
\end{tabular}

(Curacao and Suriname) lying in the upper right and lower left corners respectively), findings that tend to follow those hypothesized by sartori.

On a separate note, though direct comparison between these data and those of Lijphart is hampered by the different set of magnitudes and formulas in the two studies. examination of the data for PR systems in Tables 2 through 5 , finds the Latin American PR systems to possess a lower degree of multipartism (3.12 vs. 4.07) and a higher degree of disproportionality (9.27 vs. 4.62) than do the European PR systems. It is quite conceivable that this result is also due at least in part to the presidential nature of 12 of the 14 Latin American PR systems. These findings suggest that future work on electoral structures should examine more closely the relationship between the plurality or majority presidential election process and the PR legislative election

\section{Presidential Elections, Multipartism and Disproportionality}

Only one system in Lijphart's study featured a strong popularly elected executive and a legislature elected by proportional represenation (Finland). In our population however, over half (12) of the electoral systems possess this feature, with executives who are much more powerful vis-a-vis the legislature than is the case in Finland. Shugart (1988) has found that in electoral systems which combine presidential government with a legislature elected by $P R$, the timing of the presidential election has a profound impact on the degree of multipartism and level of disproportionality in a nation. In sum. holding other factors constant, Shugart determined that electoral systems in which the presidential and legislative elections were held concurrently tended to have fewer partics (usually nearing two) and hence more proportional results (due to the restraint placed on voting for small partics) than did systems which held presidential and legislative elections at separate times.

In the presidential-PR systems examined by Shugart the determination of concurrence is very clear cut. Infortunately this is not the case for all the Latin American presidential-PR systems analysed in this study. These systems fall under five separate categories: (1) systems in which the two elections are held concurrently and the president is elected in one round of voting (that is, not needing 50 per cent of the vote to be elected); (2) systems in which the elections are held concurrently half 
of the time and the executive is usually elected in the first round; (3) systems in which the elections are held concurrently and the executive is usually selected in a second round of voting (that is, over 50 per cent of the vote is needed to win in the first round); (4) systems in which the elections are held concurrently half of the time and the president is usualy elected in the second round; and (5) systems in which the elections are not held concurrently. For analytic purposes these five categories were collapsed firrst into three ordinal categories: concurrent, hybrid and separate. $^{12}$

Three types of analysis (the examination of cross tabulations, OLS regression analysis, and a difference of means test) provide partial support for Shugart's premise that the degree of temporal concurrence of presidential elections has an inverse relationship with the level of multipartism and hence indirectly with the amount of disproportionality of an electoral system. Examination of cross tabulations found the concurrent systems to have lower levels of disproportionality than the separate systems. However, these findings were tainted by the unhypothesized position of the hybrid system as the most fractionalized and disproportional. Within magnitude and formula analysis also yielded inconclusive results with some categories following the hypothesized trend and others confounding it. OLS regression analysis yielded similar inconclusive results. While the relationship between degree of concurrence (holding magnitude constant) and the two dependent variables was in the hypothesized direction, it was very weak. Analysis also was conducted by combining the hybrid and separate categories, yielding a binary variable. Analysis using this variable (once again holding magnitude constant), revealed that the estimated coefficients for the impact of degree of concurrence on both disproportionality and multipartism were also very modest. ${ }^{13}$ Finally, the Argentine electoral system provides us with four elections, two of which occurred concurrently with the election for president, and two occurred independently of a presidential election. A difference of means test of the levels of multipartism and disproportionality reveals support for Shugart's hypothesis with the differences for both being significant at the .1 level (one tail test). In sum, these three different types of analysis demonstrate that the timing of presidential elections does tend to have a modest impact on the level of multipartism and disproportionality in a nation. However, this impact is not as strong as suggested by Shugart. ${ }^{1+}$

\section{Summary}

Our study based on Latin American and Caribbean data has confirmed (either in whole or in part) almost all of the separate relationships among electoral formula and average district magnitude and among electoral disproportionality and electoral multipartism found by Lijphart in the Anglo-European experience. The findings most strongly supported were: the predicted relationship between formula and disproportionality (with disproportionality decreasing as one noved from the (hypothesized) least proportional system (plurality) towards the most proportional category (LR-Hare)), along with the inverse relationship posited between magnitude and disproportionality. Less well substantiated, yet nevertheless partially confirmed was the relationship between formula and multipartism (that is, a difference between plurality and PR but no monotonic difference within the PR family), as well as the small, yet positive relationship between magnitude and multipartism. Finally Lijphart's overall conclusion, that formula and magnitude have a strong 
combined impact on disproportionality, but have little influence on the number of parties in an electoral system, was confirmed using Latin American data in an examination of cross tabulations and through the use of OLS regression analysis.

While most of Lijphart's qualifiers to these general conclusions were confirmed using Latin American data, his finding of no correlation between the disproportionality and multipartism in the PR subset was not supported. Instead, a positive correlation was found to exist between disproportionality and multipartism. It was hypothesized that this counter-intuitive result was perhaps a product of the systemic interaction between a strong popularly elected president and a legislature elected using proportional representation. In sum, this study has tended to confirm (or at least not challenge) most of Lijphart's findings, which strengthens the salience of his work as a general theory and at the same time provides a practical resource for those drafting electoral laws in nations on the road to democratization. Finally, the impact of the timing of presidential elections on PR legislative systems, a factor which had been previously shown to have a strong impact on the fractionalization and proportionality of electoral systems, was only modestly supported by the data here.

\section{Conclusion}

Our analysis represents an attempt to apply a portion of a theory derived from the study of Anglo-European nations to a region with a cultural, historical, and economic make-up markedly different from that of these highly developed Western nations. The results of this study have strengthened the generalizability of Lijphart's revision of Rae's theoretical argument about the impact of electoral laws on party systems for it is applicable to at least one set of non-Anglo-European systems, and by inference to others. This study also has demonstrated the applicability of the theory to party systems in a region with cultures, histories, and economic profiles which are radically different from those of the nations upon which Rae based his model, and from which Lijphart re-analysed that model. The salient point to be drawn from this discussion is that electoral laws do matter. That despite the existence of a host of 'social, economic, legal, and political' (Rac, 1971:111) differences between the nations in this study and those examined by Rac and Lijphart, certain electoral laws (that is, formula, magnitude) for the most part affected aspects of the party systems (that is disproportionality, multipartism) in these latin American and Caribbean countries in ways similar to those found by Lijphart in his study of the Anglo-European democracies.

The findings of this study also have practical implications for nations of the world which are courently in the process of democratization. In the next decale politicians and bureaucrats in many countries will be involved in drafting and modifying electoral laws which will have a profound impact on the future of the nations' political systems. Decisions made now about which electoral formula to usc and what size to make the electoral districts will influence a variety of factors in a country such as the representation of minority and regional interests, and to a lesser extent the existence of fringe and centrist parties.

Future work on the impact of electoral laws on Latin American and Caribbean party systems would be enhanced by the collection and publication of more complete electoral data for the region. These data would not only increase the number of elections which could be used to analyse each party system, but would 
also raise the number of systems within the sample. Future studies might also go beyond the Western Hemisphere to analyse both separately, and in conjunction with the data user here, select party systems in Africa, Asia, Eastern Europe and Oceania. These contributions would not only help the evaluation of Lijphart's reanalysis as a basic general theory of the impact of electoral laws, but would also provide a useful resource to policy makers attempting to craft an electoral system that is ideal for their specific nation.

\section{Notes}

1. In one of the most noted reviews of the field of electoral systems research (Lijphart, 1985) an overwhelming majority of the works cited by Lijphart as 'significant' possess an almost exclusive Anglo-European focus. An exception is Nohlen (1978).

2. The countries which comprise Rae's and thus Lijphart's samples are: Australia, Austria, Belgium, Canada, Denmark, Finland, France, West Germany, Great Britain, Iceland, Ireland, Israel, Italy, Luxembourg, the Netherlands, New Zealand, Norway, Sweden, Switzerland and the United States (Rae, 1971, Appendix C).

3. Disproportionality represents the sum of the differences between the vote proportions and the seat proportions' divided by two. $D=1 / 2$ Sum of all cases $[V-S]$ where ' $D$ is (one half of) the extent to which the distribution of seats won $S$ does not mirror the distribution of votes cast $V$ for all parties' (Loosemore and Hanby, 1971: 468-9).

4. Multipartism is measured using the same fractionalization index used by Lijphart, where the index of fractionalization is represented by $F$ and the effective number of parties by $N^{\prime}$ (1990; 494) in the equation $\mathrm{N}=1 /(1-\mathrm{F})$ where $\mathrm{F}=1$-the sum of the squared vote shares of each party. This is Laakso and Taagepera's (1979) measure of the 'effective' number of parties in an electoral system.

5. The following is the list of the sources of electoral data for each individual country. Argentina (Fraga, 1989), (De Riz and Feldman, 1988). Bahamas: (Gorvin, 1989), (Hughes, 1981). Barbados: (Gorvin, 1989), (Inter-Parliamentary Union (IPU), 1981-82, 1986-87). Belize: (Corvin, 1989), (IPU, 1989-90). Bolivia: (Honorable Corte Nacional Llectoral, 1990). Chile (IPU, 1968-69, 1972-73), (Lirzua, 1986). Colombia: (Archer, 1991), (Nohlen, 1978), (Noriega, 1979), (IPU, 1985-86). Costa Rica: (Tribunal Supremo de Elecciones, 1990), (IIcrnandez, 1986), (Lconard and Natkicl, 1986), (Ruddle and Gillette, 1972), (Wells, 1966a). Curacao: (Rac and Nishizawa, 1988). Dominica: (IPU, 1985-86, 1980-81). Dominican Republic: (Listin Diario, 06/12/90), (Brea Franco, 1987), (Diaz Santana and Murphy, 1983). Ecuador: (Darlic Mardesic, 1987). El Salvador: (CINAS, 1991), (Jimenez, et al, 1988). Guatemala: (Libreria Mafcuense, 1986). Honduras: (IPU, 1989-90), (Delgado, 1986). Jamaica: (Stone, 1989), (Waters, 1986). Puerto Rico: (Comision Electoral Estatal, 1981), (Tribunal Electoral, 1977), (Junta Estatal de Elecciones, 1974, 1968, 1964). St Lucia: (Gorvin, 1989), (IPU, 1979-80). Suriname: (Sedney, 1980). Trinidad and Tobago: (Gorvin, 1989), (IPU, 1986-87, 1976-77, 1970-71), (Leonard and Natkiel, 1986). Uruguay: (Libreria Linardi and Risso, 1989), (Centro de Estudios Latinoamericanos, 1986), (Wells, 1966b), (Fabregat, 1950, 1957, 1964). Venezuela: (IPU, 1988-89), (Chang Mota, 1985), (Penniman, 1980). General Sources: (McDonald and Kuhl, 1989), (Capel, 1986).

6. Elections for which data were collected yet were excluded due to their lack of amenability to Lijphart's classificatory schema were: Argentina 1973, due to the use of a 8 per cent vote threshold at the district level which renders the election non-comparable to the 1983-89 elections where a 3 per cent threshold was employed; Brazil 1946-62 and 1985-, due to the large scale use of alliance lists for which the vote was recorded for the alliances, not the individual parties; Chile 1989, due to the radically different magnitude employed; Paraguay 1989, due to the feature of the system which allocates two- 
thirds of the legislative seats to the party which receives the largest percentage of the vote. Peru was not included in the study due to an inability to locate suitable electoral data for lower house elections in that nation. Similarly the 197 i costa Rican legislative election was excluded due to the lack of adequatc electoral results.

7. Due to the lack of a standard resource of electoral statistics for Latin Americal and the (aribbean such as exists for the Anglo-European democracies (Mackic and Rosc, 1991). some modifications and estimation took place in the preparation of the data in this study for final analysis. The following section details the modifications, ete. for cach country/territory. Colombia: in 1986 Colombian partics began to run coalitions in some clistricts, thus complicating any statistical measurement of clectoral restults. ciuided by the work of Ronald Archer (Archer, 1991) I was able to make a rough estimate of the degrees of disproportionality and multipartism for 1986. Due to increased use of these coalitions in the 1990 election, data from that election are not included in this analysis. I am particularly indebted to Ronald Archer for his insights on this topic. Colombia employs the Hare electoral formula for all legislative districts except those with two representatives for which the Droop formula is utilized. Here. Colombia is included in the Harc category. Ecuador: this system has in addition to the 59 provincial deputies clected biannually, 12 national deputies elected every four years. since these national deputies are elected on a separate hallot from the provincial deputies, the possibility of including them in this analysis was foreclosed, and thus here only data regarding the provincial deputies are utilized, and Ecuadlor thus is not boosted up one magnitude category. Also, while Ecuator does not use the d'Hondt electoral formula, it is placed in the dilondt category since its formula is most similar in nature to the d' Hondt formula. Guatemala: the civatenalan legislature is composed of 100 members. 75 of whom are cected from provincial districts, and 25 on a separate ballot from a national list. As wals the case for Ecuador. analysis was restricted to those deputies elected at the district level. and cilatemala was thus not boosted up one magnitude category. Honduras: since Honduras only utilized a six seat cout of 13.t) second tier in one of the two elections examined (1985), it was not boosted up onc magnitude category. Puerto Rico: as wats the casc with Ecuador and Guatemala, the lack of aggregate electoral data prevents the inclusion of the deputics by accumulation' usually 11 but often morc. who are clected at large in a complicated manner, $A$ s a result only data for the single-member districts are used here, and Pueter Rico is not boosted up one magnitude calcegry. Suriname: due to the use of separate ballots (o) elece kegislative members at dhe district level and at loc national level, only (tata for the more salient (27 of the 39 members of parliament) ckection will be included in this analysis. It should also be noted that six of the 27 presincial legislators are elected from two-member plurality districts. Ideally surinane would be lowered one magnitude catcgory due to this fact. However since with a magnitude of 2.7 . the lower category is the plutality one and since the nation's magnitude is aldeady

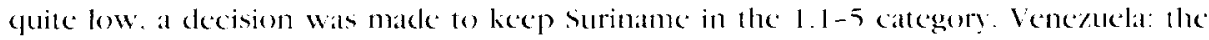
nation has a second tier electoral district, and is thus boosted up one magnitude cattegory.

8 . When examining the independent impact of formula and magnitude on clisproportionality. Lijphart is advantaged in that many of the nations in his study switehed their formulat and or district magnitude at some point since 19.15 (Pp. f88-9), thus allowing him to better examine the independent effect of both formula and magnitude. In latin Ancrica the relative lack of formula and magnitude change along witlo other extentating factors in the few cases where it occurred-magnitude change only-ece. such as a very small number of elections) renders this type of analysis inappropriate at this juncture.

9. The magnitude catcgories used by Lijphart were retained for comparability, and in the case of those systems which utilize complex-districting, every attempt was made to follow Lijphart's advice and raise them one category. However, for four of these systems (Ecuador, Guatemala, Puerto Rico, Suriname) only data for the lower tier elections 
(deemed the most important in all four cases) were used because in each country the upper tier legislators are elected on a separate ballot.

10. In the OLS regression analysis employed in this study: formula was measured using a logged dummy variable which divided the systems between PR and plurality systems, magnitude was measured using the log of the actual district magnitude (Shugart, 1988) (except in the case of Venezuela which had one adjusted magnitude added to its average disrict magnitude to compensate for its second-tier elections), and finally the timing of presidential elections was measured by both a logged three and two point variable which is more fully described in the section on the timing of presidential elections.

11. The case of Ecuador was excluded from the cross tab analysis of multipartism due to its highly unusual party system (fractionalization $=10.85$ ). For similar reasons it was also excluded from all regression analysis examining the impact of magnitude and the timing of presidential elections on multipartism.

12. The countries in each of the five categories are as follows: (1) Costa Rica, Dominican Republic, Honduras, Uruguay, Venezuela; (2) Argentina; (3) Bolivia, Guatemala; (4) Fcuador; (5) Chile, Colombia, El Salvador Concurrent: (1); Hyhrid: $(2,3,4)$; Se parate: (5)

13. The estimated coefficients and $t$-ratios for the impact of ( $\log$ scalc) the three point presidential timing variable (holding magnitude constant) on disproportionality and multipartism (with nine degrees of freedom for disproportionality and eight for multipartism due to the exclusion of Ecuador from the latter category) were $(.178,1-.408)$ and $(.233$, t-.944) respectively. For the same test using the binary presidential timing variable the results were $(.193, t-1.145)$ and $(.124, t-1.275)$.

14. Preliminary data analysis in a current project has tentatively provided stronger support for Shugart's hypothesis than have the data examined here.

\section{References}

Ronald P. Archer, unpublished manuscript, (Durham: Duke Liniversity, 1991).

Julio Brea Franco, 'Reforma Electoral y Representacion Politica en la Sistema Electoral

Dominicano,' in Sistemas Electorales y' Representacion Politica en Latinoamerica, Vol. 2. (Madrid: Fundacion Friedrich Ebert, 1987), pp. 227-65.

Centro de Asesoria y Promocion Electoral (CAPEl), Legislacion Flectoral Comparada: Colombia, Mexico, Panama, Venezuela y Centroamerica, (San Jose, Costa Rica: CAPEL, 1986).

Centro de Estudios Latinoamericanos, Estadisticas Uruguayas 1932-1984, (Buenos Aires: Centro de Estudios Latinoamericanos, 1985).

Centro de Investigacion y Accion Social (CINAS), El Sallador Boletin de Analisis e Informacion, 7, (San Salvador: CINAS, 1991).

Roberto Chang Mota, El Sistema Electoral Venezolano: Su Diseno, Implantacion " Resultados, (Caracas: Consejo Supremo Electoral, 1985).

Consejo Central de Elecciones, Et Salvador: Elecciones Marzo 1982, (San Salvador: Consejo) Central de Elecciones, 1982).

Comision Estatal de Elecciones, Elecciones Generales 1980): Informe Estadistico, (San Juan, Pucrto Rico: Caribbean Stationery, 1981).

Vjekoslav Darlic Mardesic, Estadisticas Electorales de Ecuador 1978-1987, (Quito: ILDIS, 1987 ).

Anibal Delgado Fiallos, Honduras Elecciones (Mas alla de la fiesta civica) 85. (Tegucigalpa, Honduras: Editorial Guaymuras, 1986).

Liliana De Riz and Eduardo Feldman, Guia del Parlamento Argentino, Poder Legislativo: Confirmacion, Naturaleza, y Funciones, (Bucnos Aires: Fundacion Friedrich Ebert, 1988).

Larry Diamond, Juan J. Linz and Seymour Martin Lipset (editors), Politics in Developing Countries: Comparing Experiences with Democracy, (Boulder: Lynne Rienner, 1990).

Miriam Diaz Santana and Martin F. Murphy, The 1982 National Elections in the Dominican Republic: A Sociological and Historical Interpretation, (Kio Piedras, Puerto Rico: The Institute of Caribbean Studies, University of Puerto Rico, 1983).

Maurice Duverger, Political Parties, (New York: John Wiley, 1954). 
Julio T. Fabregat, Elecciones Uruguayas: Febrero de 1925 a Noviembre de 1946, (Montevideo: Republica Oriental de Uruguay Poder Legislativo, 1950).

Julio T. Fabregat, Elecciones Uruguayas de Noviembre de 1950 a Noviembre de 1954, (Montevideo: Republica Oriental de Uruguay Camara de Representantes, 1957).

Julio T. Fabregat, Elecciones de 25 de Noviembre 1962, (Montevideo: Republica Oriental de Uruguay Camara de Senadores, 1964).

Rosendo Fraga, Argentina en las Urnas 1916-1989, (Buenos Aires, Centro de Estudios para la Nueva Mayoria, 1989).

Ian Gorvin (editor), Elections Since 1945: A Worldwide Reference Compendium, (Chicago: Longman International Reference, 1989).

Ruben Hernandez Valle, Costa Rica: Elecciones de 1986. Analisis de los Resultados, (San Jose, Costa Rica: IIDH-CAPEL, 1986).

Honorable Corte Nacional Electoral, Elecciones Generales 1985-1989. (La Paz: Honorable Corte Nacional Electoral, 1990).

Colin A. Hughes, Race and Politics in the Babamas, (New York: St Martin's Press, 1981).

Inter-Parliamentary Union, Chronicle of Parliamentary Elections and Developments, Years 1965-1990, (Geneva: International Centre for Parliamentary Documentation, 1966-90.

Edgar C. Jimenez, et al. El Savador: Guerra, Politica y Paz (1979-1988), (San Salvador: CINAS, 1988).

Junta Estatal de Elecciones, Informe Oficial Sobre las Elecciones Generales de 1972. (San Juan, Puerto Rico: Administracion de Servicios Generales, 1974).

Junta Estatal de Elecciones, Puerto Rico: Estadistica Electoral Sobre las Elecciones Generales de 1968, (San Juan: Junta Estatal de Elecciones, 1968).

Junta Estatal de Elecciones, Puerto Rico: Estadistica Electoral Sobre las Elecciones Generales de 1964, (San Juan: Junta Estatal de Elecciones, 1964).

Keesing's Contemporary Archives, (Bristol: Keesing's Publications, 1975-91).

Markku Laakso and Rein Taagepera, 'Effective Number of Parties: A Measure With Application to West Europe', Comparative Political Studies, 12, 1979, pp. 3-27.

Dick Leonard and Richard Natkiel, World Atlas of Elections: Voting Patterns in 39 Democracies, (London: The Economist Publications Limited, 1986).

Libreria Linardi y Risso, Uruguay Elecciones Nacionales 26 de Noviembre de 1989: Compilacion de Folletos, Panfletos y Hojas de Votacion de Todos los Partidos Politicos, (Montevideo: Libreria Linardi y Risso, 1989).

Libreria Mafcuense, Memoria de las Elecciones Generales Celebrados en los Meses de Noviembre y Diciembre de 1985, (Antigua, Guatemala: Libreria Mafcuense, 1986).

Arend Lijphart, 'The Field of Electoral Systems Research: A Critical Survey', Electoral Studies, 4: 1, 1985, pp. 3-14.

Arend Lijphart, 'The Political Consequences of Electoral Laws, 1945-85', American Political Science Review, 80, 1990, pp. 481-96.

Listin Diario, 06/12/90, p.12.

John Loosemore and Victor J. Hanby, 'The Theoretical Limits of Maximum Distortion: Some Analytic Expressions for Electoral Systems', British Journal of Political Science, 1, 1971, pp. 467-77.

Ronald H. McDonald and J. Mark Ruhl, Party Politics and Elections in Latin America, (Boulder: Westview Press, 1989).

T. Thomas Mackie and Richard Rose The International Almanac of Electoral History, 3rd edn, (Washington, DC: Congressional Quarterly, 1991).

Dieter Nohlen, Wahlsysteme der Welt-Daten und Analysen: Fin Handhuch, (Munich: Piper, 1978).

Carlos Augosto Noriega 'Los Resultados Electorales y Su Significado Politico', in Rodrigo Losada Lora and George Liebig (editors), Las Elecciones de 1978 en Colombia, (Bogota: Fundacion Friedrich Ebert, 1979), pp. 47-102.

Howard R. Penniman (editor), Venezuela At the Polls: The National Elections of 1978, (Washington, DC: American Enterprise Institute for Public Policy Research, 1980).

Douglas W. Rae, The Political Consequences of Electoral Laws, 2nd edn, (New Haven: Yale University Press, 1971).

Douglas Rae and Yoshitaka Nishizawa, An Electoral System for Curacao: Consulting Document Prepared for Kousa Komun, (New Haven: Yale University Press, 1988).

Kenneth Ruddle and Philip Gillette (editors), Latin American Political Statistics: Supplement 
to the Statistical Abstract of Latin America, (Los Angeles: Latin American Center. University of California, Los Angeles, 1972).

Giovanni Sartori, Parties and Party Systems: A Frameu'ork for Analysis, (Cambridge: Cambridge University Press, 1976).

Giovanni Sartori, 'The Influence of Electoral Systems: Faulty Laws or Faulty Methods?' in Bernard Grofman and Arend Lijphart (editors), Electoral Lau's and Their Political Consequences, (New York: Agathon, 1986).

Julcs Scdncy, Politieke Partijen in Suriname Vermenigulddigen Zich als la Gere Organisem: Door Splitsing en Deling, (Paramaribo: Kiezen en Delen, 1980).

Matthew S. Shugart, 'Duverger's Rule, District Magnitude, and Presidentialism', Ph. D. dissertation, (University of California, Irvine, 1988).

Carl Stone, Politics Versus Economics: The 1989 Elections in Jamaica, (Kingston: Heinemann, 1989).

Rein Taagepera and Matthew S. Shugart, Seals and Voles: The Effects and Determinants of Electoral Systems, (New Haven; Yale Inniversity Press, 1989).

Tribunal Electoral, Elecciones 1976, (San Juan, Puerto Rico: Tribunal Electoral, 1977).

Tribunal Supremo de Elecciones, Compulo de Votos y Declatorias de Eleccion-1990, (San Jose, Costa Rica: Imprenta Nacional, 1990).

German Irzua Valenzuela, Historia Politica Electoral de Chile 1931-1973, (Santiago de Chile: Tarmacos, 1986).

Anita M. Waters, Race, Class and Political Symbols: Rastafari and Reggae in Jamaican Politics, (New Brunswick: Transaction Books, 1985).

Henry Wells (editor) (1966a), Costa Rica Flection Factbook: February 6 1966, (Washington, DC: Institute for the Comparative Study of Political Systems, 1966).

Henry Wells (editor) (1966b), Uruguay, Flection Faclbook: November 27 1966, (Washington, DC: Institute for the Comparative Study of Political Systems, 1966). 